\title{
Pembekalan Materi Pembelajaran Pemberaian Batuan (Rock Excavation) Di Smk Muhammadiyah Jurusan Geologi Pertambangan Kota Jambi
}

\author{
Faizar Farid, Aditya Denny Prabawa*, M. Ikrar Lagowa, Jarot Wiratama, Yosha \\ Megasukma, Luthfi Wahyudi, Wahyudi Zahar \\ Fakultas Sains dan Teknologi, Universitas Jambi, Indonesia \\ Email:aditya.mining@unja.ac.id
}

\begin{abstract}
ABSTRAK
SMK Muhammadiyah Kota Jambi adalah sebuah sekolah menengah kejuruan swasta yang berdiri pada tanggal 27 Maret 2014. SMK ini berlokasi di Jl, Guntur No.2 Rt.8, Kelurahan Kasang, Kec. Jambi Timur, Kota Jambi. Status SMK Muhammadiyah Kota Jambi saat ini belum terakreditasi dan sedang dalam tahap pengajuan. Sedangkan kurikulum pembelajaran yang dipakai yaitu KTSP (Kurikulum Tingkat Satuan Pendidikan). SMK memiliki dua jurusan utama yakni perbankan syariah dan geologi pertambangan.Permasalahan yang di hadapi SMK Muhammadiyah yakni belum terakreditasinya sekolah, Sarana dan prasarana yang belum memadai, terutama yang berkaitan langsung dengan proses belajar mengajar, diantaranya: laboratorium, sampel batuan dan mineral, alat ukur dan gps, dll, Kurangnya jumlah guru yang memiliki kompetensi di bidang pertambangan . Belum adanya kerjasama dengan stakeholder terkait, misalnya SMK Geologi/ Pertambangan lain, universitas, maupun instansi dan perusahaan yang berkaitan dengan Pertambangan, Kurangnya kegiatan kunjungan lapangan. Program Studi Teknik Pertambangan Universitas Jambi dalam kapasitasnya sebagai institusi pendidikan tinggi yang rgerak di bidang pertambangan berniat untuk berkontribusi dan bekerjasama dengan pihak SMK Muhammadiyah Jambi untuk menjawab permasalahan rendahnya kualitas proses belajar mengajar, khususnya pada jurusan Geologi Pertambangan, dengan program pengabdian kepada masyarakat yang berjudul "Pembekalan Materi Pembelajaran Pemberaian Batuan (Rock Excavation) di SMK Muhammadiyah Jurusan Geologi Pertambangan”. dengan hasil akhir kegiatan pengabdian yakni buku ajar dan jurnal ilmiah.
\end{abstract}

Kata Kunci : Pembekalan Materi, Pemberian Bantuan, Pengabdian.

\section{PENDAHULUAN}

SMK Muhammadiyah Kota Jambi adalah sebuah sekolah menengah kejuruan swasta yang berdiri pada tanggal 27 Maret 2014. SMK ini berlokasi di Jl, Guntur No.2 Rt.8, kelurahan Kasang, Kec. Jambi Timur, Kota Jambi dengan koordinat lintang -1.5984570 dan bujur 103.6708180. Ada dua jurusan di SMK Muhammadiyah Kota Jambi, yaitu Perbankan dan Geologi Pertambangan dengan total jumlah siswa 52 orang yang dibagi ke dalam 6 kelas, dan total jumlah guru 9 orang. Dari 9 orang guru ini, hanya 2 orang yang memiliki latar belakang pendidikan dan pekerjaan di bidang pertambangan.

Status SMK Muhammadiyah Kota Jambi saat ini belum terakreditasi dan sedang dalam tahap pengajuan. Sedangkan kurikulum pembelajaran yang dipakai yaitu KTSP (Kurikulum Tingkat Satuan Pendidikan).

\section{METODE PELAKSANAAN}

\section{Kunjungan Awal}

Kegiatan ini dilakukan sebagai survei awal tim pelaksana terhadap lokasi sekolah dan kondisi kegiatan belajar mengajar di SMK Muhammadiyah Kota Jambi sekaligus diskusi 
dengan para guru untuk mempersiapkan pelaksanaan pembekalan pembelajaran. Pada kunjungan awal ini juga akan dilakukan sosialisasi program pembekalan pembelajaran ini kepada para siswa jurusan Geologi Pertambangan.

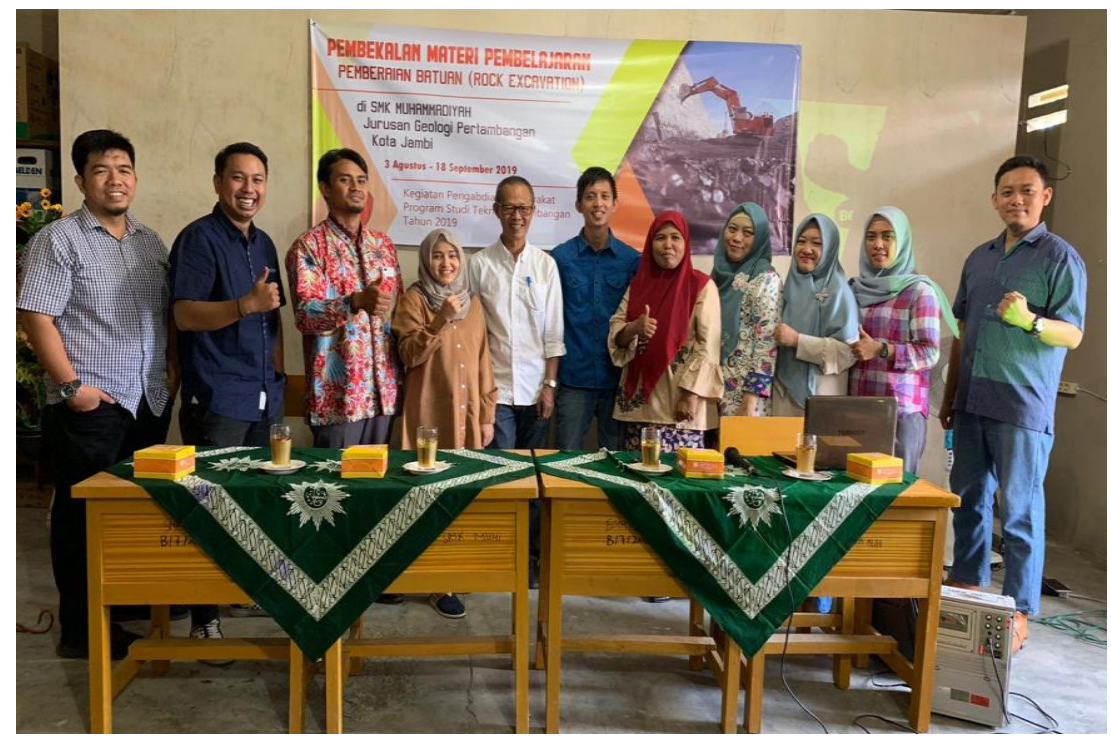

Gambar 1: Dosen teknik pertambangan berserta guru SMK Muhammadiyah

\section{Preliminary Test}

Setelah dilakukan kegiatan sosialisasi program pembekalan pembelajaran kepada kepada para siswa jurusan Geologi Pertambangan SMK Muhammadiyah, kegiatan selanjutnya yang dilakukan adalah studi pendahuluan. Studi pendahuluan adalah proses mengumpulkan berbagai informasi (data) awal terkait dengan rencana pembekalan pembelajaran tentang materi Pemberaian Batuan (Rock Excavation), yang dilakukan dalam rangka mengukur menemukan dan mendalami masalah secara lebih sistematis dan intensif. Studi pendahuluan juga disebut pilot studi atau preliminary study. Tujuan lain dilakukannya preliminary study ini juga dapat digunakan sebagai output perbandingan keberhasilan Pembekalan Materi Pembelajaran Pemberaian Batuan (Rock Excavation) di SMK Muhammadiyah Jurusan Geologi Pertambangan. 


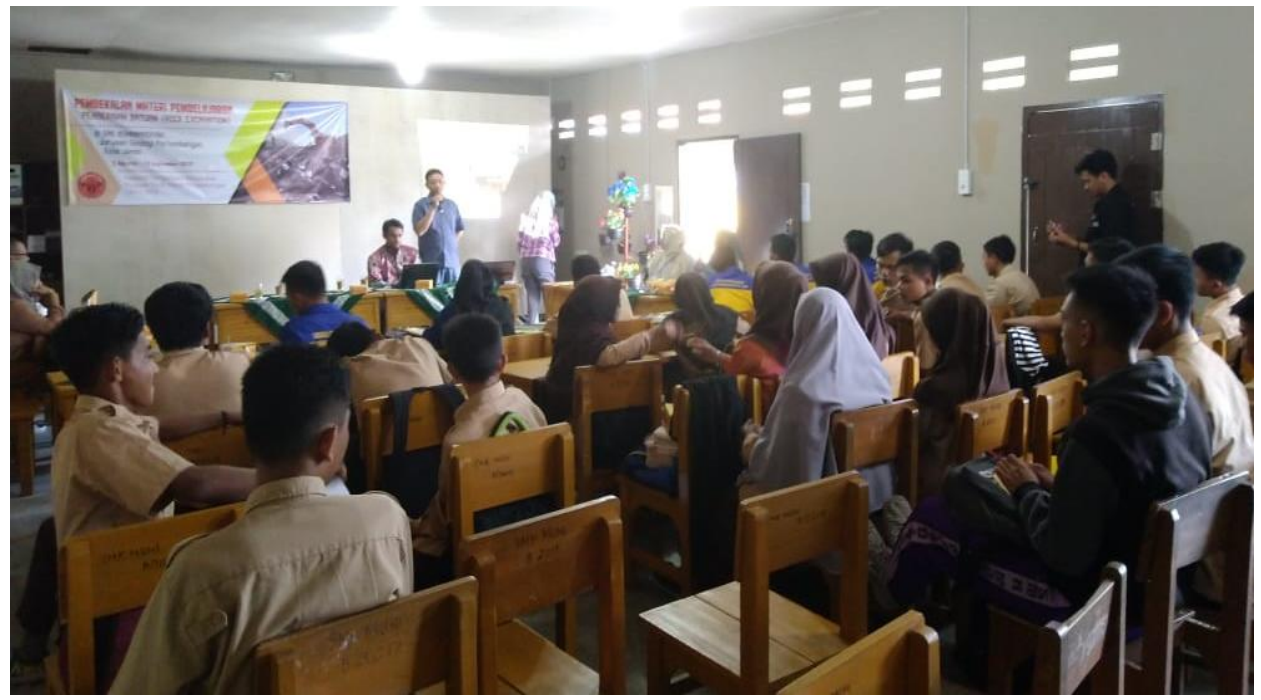

\section{Penyampaian Materi}

Gambar 2. Preliminary Test

Materi dalam Pemberaian Batuan (Rock Excavation) adalah materi pendukung dari mata pelajaran Ilmu Batuan dan mata pelajaran lain yang terkait. Diantara materi-materi yang akan diajarkan kepada para siswa adalah: Dasar Mekanika Batuan, Dasar Mekanika Tanah, Pemindahan Tanah Mekanis, Teknik Peledakan. Metode pembelajaran yang akan dipakai adalah ceramah, diskusi, tanya jawab, dan tugas mandiri (individu).

Gambar 3. Pemaparan Materi Oleh Dosen Teknik Pertambangan

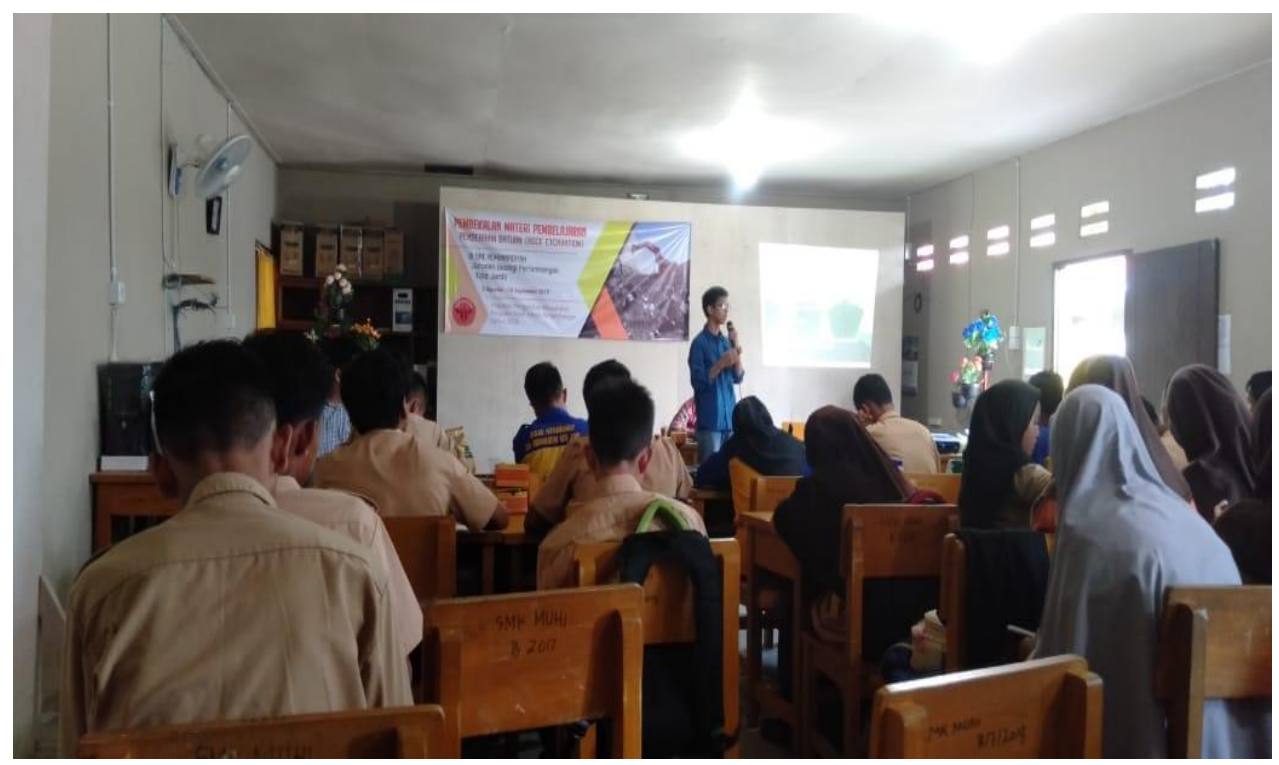

\section{Penyusunan Draf Buku Ajar}

Setiap selesai pemberian materi, tim pelaksana dan pengabdian melaksanakan evaluasi pembelajaran untuk menyusun konten buku ajar yang sesuai dengan nantinya akan 6 dicetak untuk kalangan sendiri (internal sekolah) dan dipakai untuk mendukung proses belajar mengajar di jurusan geologi kebumian SMK Muhammadiyah Kota Jambi. 


\section{Evaluasi}

Pada pertemuan terakhir, pelaksanaan pengabdian ini dievaluasi dengan melibatkan seluruh pihak terkait, baik tim pelaksana, para guru, dan para siswa. Evaluasi dilakukan dengan pengisian angket oleh mahasiswa dan penyampaian umpan balik secara langsung dari masing-masing pihak terhadap kontribusi masing-masing di dalam pelaksanaan kegiatan pengabdian ini.

\section{HASIL DAN PEMBAHASAN}

Pada awal pembekalan materi mahasiswa diberikan ice breaking, dengan memberikan pertanyaan - pertanyaan tentang materi yang berkaitan. Pertanyaan - pertanyaan bertujuan untuk memberikan rangsangan untuk berpikir dan mereview kembali pengetahuan yang mungkin telah mereka dapat dari bangku sekolah. Tingkat penyampaian materi dari semua narasumber pun diusahakan sesuai berdasarkan tingkat KKNI. Pada materi Genesa Bahan Galian diberikan oleh Wahyudi Zahar, S.T, M.T. dan Jarot Wiratama, S.T, M.T selaku dosen bidang keahlian eksplorasi sumber daya bumi. Pada materi pertama oleh Wahyudi Zahar S.T,M.T. dijelaskan konsep - konsep eksplorasi untuk menemukan bahan galian , tahapan tahapan eksplorasi, karakteristik kegiatan eksplorasi. Pada bagian ini juga dijelaskan metode eksplorasi secara langsung dimana berhubungan dengan metode yang kontak langsung dengan bahan galian, seperti trenching, tracing float, tracing float, sumur uji. Dan juga dijelaskan metode sampling, dikarenakan karakteristik bahan galian berbeda maka dibutuhkan metode sampling yang berbeda.

Pada Pertemua kedua, siswa diberikan materi tentang mekanika batuan/pemberaian batuan yang di ajarkan oleh Aditya Denny Prabawa S.T, M.T. materi tersebut membahas mengenai proses pecahnya batuan dan prasyarat batuan tersebut di ledakan dalam kegiatan penambangan. Siswa diajarkan mengenai hubungan antara gaya, tekanan dan prosec pecahnya batuan. Pemebraian siswa diajarkan mengenai geometri lubang ledak dan proses kegiatan peledakan pada tambang terbuka.

Pada pertemuan ketiga, siswa diberikan materi mengenai pemindahan tanah mekanis. Materi tersebut diajarkan oleh Yosa Megasukma S.T, M.T dan Luthi Wahyudi S.T, M.T. Materi membahas mengenai proses pemilihan alat mekanis yang digunakan pada kegiatan penambangan, prasyarat pemilhan alat mekanis, dan keserasian alat mekanis yang mesti tercapai pada saat proses penambangan.

Pada pertemua keempat, tim pengabdian yang terdiri dari dosen dan mahasiswa teknik pertambangan mengadakan simulasi praktikum peledakan pada tambang terbuka. Materi ini membahas mengenai proses terjadinya ledakan, perhitungan geometri lubang ledak, serta menunjukan mengenai rangkaian peledakan, pada simulasi ini siswa dilihatkan bentuk dinamit, kabel yang digunkan di peledakan, rangkaian peledakan, dan ANFO.

Pada pertemua kelima, siswa diajarkan mengenai proses peremukan dan pengolahan bahan galian yang diperoloh dari kegiatan penambangan. Materi ini diajarkan oleh Muhammad Ikrar Lagowa, S.T, M.Eng, Sc. Materi membahas mengenai proses pengolahan bahan galian agar sesuai dengan ukuran dan spesifikasi yang dibutuhkan oleh konsumen. Dimulai dari proses pemilihan Crusher, Material Balance, dan proses perancangan pabrik peremuk 


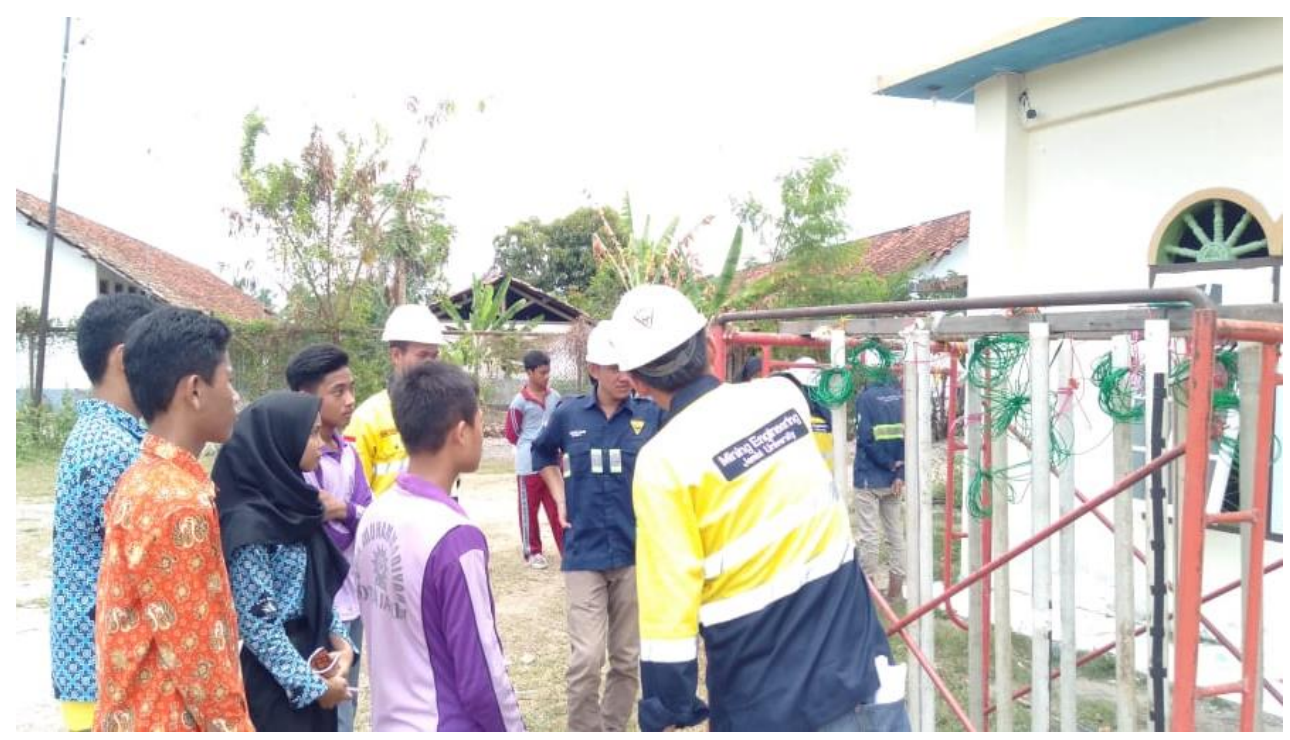

Gambar 4: Simulasi Peletakan Pada Tambang Terbuka

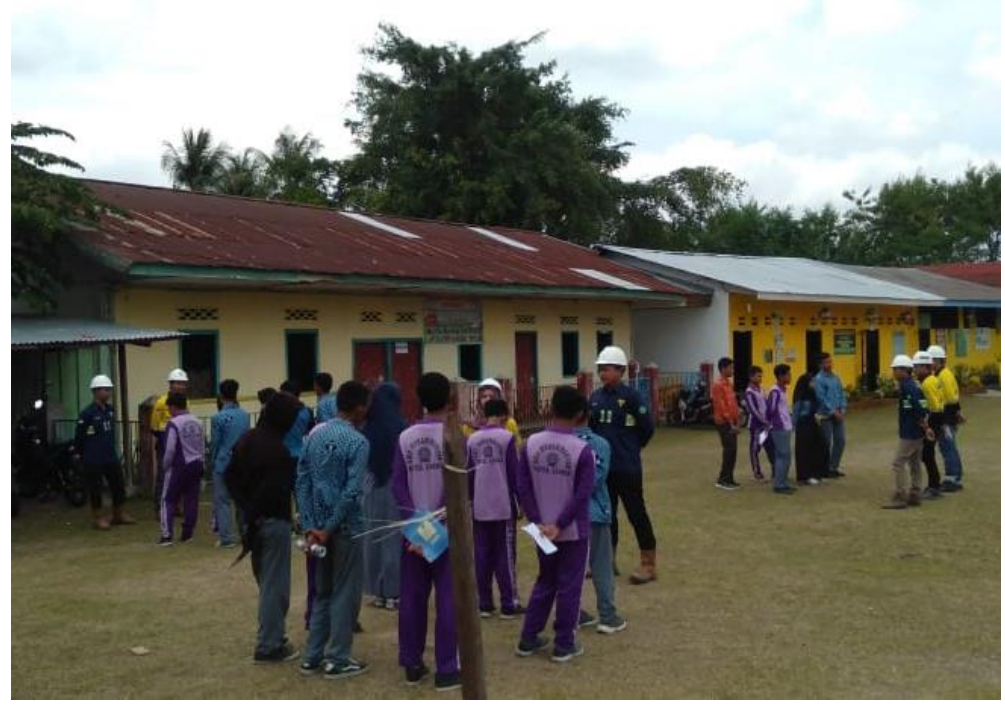

Gambar 5. Pembagian Diskusi Dalam Kelompok Kecil Antara Mahasiswa Teknik Pertambangan dan Siswa SMK

Pada setiap pertemuan siswa diarahkan mengenai pemilihan pekerjaan dan keahlian bidang kerja di dunia pertambangan. Dengan pengabdian dilaksanakan di SMK muhammadiyah diharapkan minat siswa yang sekolah dapat semakin semangat dan berjuang untuk menyelesaikan masa studinya. Siswa mendapatkan gambaran dalam menumpuh dan mengambil keputusan saat lulus sekolah. Siswa memilih langsung masuk dunia kerja pertambangan ataupun menempuh jenjang lebih tinggi lagi yakni kuliah di prodi teknik pertambangan. 


\section{KESIMPULAN DAN SARAN}

Berdasarkan uraian yang telah dikemukakan pada bagian sebelumnya, diperoleh kesimpulan bahwa kegiatan pengabdian kepada masyarakat ini dapat :

1. Meningkatkan Pengetahuan dan Keterampilan Siswa di SMK Muhammadiyah Kota Jambi tentang proses kegiatan penambangan dari tahap eksplorasi sampai proses pengolahaan bahan galian

2. Meningkatkan pemahaman siswa tentang kegiatan pemberaian batuan terutama pada tambang terbuka.

3. Memberikan gambaran pada siswa mengenai macam-macam kegiatan dan keahlian di pertambangan.

Berdasarkan kepada hasil yang diperoleh maka dapat disarankan beberapa hal sebagai berikut.

1. Dari masukan sekolah hendaknya kegiatan-kegiatan seperti ini dapat dilakukan dengan jangka waktu yang panjang.

2. Biaya untuk pelaksanaan kegiatan pengabdian ini lebih ditingkatkan, sehingga dapat dilakukan lebih banyak materi yang dapat disampaiakn dan waktu pelaksanaan dapat lebih lama.

\section{DAFTAR PUSTAKA}

Akar G. Uner Ipekoglu. 2007. Relationship between Ash Fusion Temperatures (AFT) and Coal Mineral Matter in some Turkish Coal Ashes. The Journal of ORE DRESSING. Vol $9-17$

Amand L, E,Couch and Leckner B. ( 2001). Co - Combustion of Sewege Sludge with Wood/ Coal in a Circulating Fluidized Bed Boiler - A Study of Gaseous Emissions. Sweden. Department of Energy Conversion Chalmers University of Technology.

Baltimore, 2006.Annual Book of ASTM Standards. ASTM Publisher,.

California Environmental Protection Agency.2010. Recomended Area Designations for 2010 Federal Sulfur Dioxide ( SO2) Standard. Air Resource Board.

Chen W. (2010) Clean Coal Technology Development in China. Energy Policy

Kaymakci, E, Hare. 2002. Relations beetween Coal Properties and Spontaneous Combustion Parameters. Turkey : Journal Engineering Environmental Science 26, 59-64.

R. Hatt, Correlating the Slagging of a Utility Boiler with Coal Characteristics, Engineering Foundation Conference, Waterville Valey, New Hampshire, USA, July 16 -22 (2000)

Yakub, Arbie,Pengambilan, Preparasi, dan Pengujian Conto Batubara,ATC course material. ATQ. 